\title{
ASYNCHRONEITY OF MAXIMUM GLACIER ADVANCES IN THE CENTRAL SPANISH PYRENEES
}

José M. García-Ruiz, Blas L.Valero-Garcés, Carlos Martí-Bono \& Penélope GonzálezSampériz

Instituto Pirenaico de Ecología, CSIC, Campus de Aula Dei, Apartado 202, 50080-

Zaragoza, Spain.

e-mail: humberto@ipe.csic.es

\begin{abstract}
The deglaciation history of the Escarra and Lana Mayor glaciers (Upper Gállego valley, Central Spanish Pyrenees) was reconstructed on the basis of detailed geomorphological studies of glacier deposits, sedimentological and palynological analyses of glacial lakes sediments and an AMS chronology based on minimum ages from glacial lake deposits. The maximum extent of the Pyrenean glaciers during the last glaciation was before 30,000 years B.P. and predated the maximum advances of the Scandinavian Ice Sheet and some Alpine glaciers. A later advance occurred during the coldest period (around 20,000 years B.P.) synchronous with the maximum global ice extent, but in the Pyrenees it was less extensive than the previous one. Later, there were minor advances followed by a stage of debris-covered glaciers and a phase of moraine formation near cirque backwalls. The deglaciation chronology of the Upper Gállego valley provides more examples of the general asynchroneity between mountain and continental glaciers. The asynchroneity of maximum advances may be explained by different regional responses to climatic forcing and by the southern latitudes of the Pyrenees.

KEYWORDS: Last Glacial Maximum, Glaciers, Upper Gállego Valley, Central Spanish Pyrenees.
\end{abstract}

Correspondence to: José M. García-Ruiz, Instituto Pirenaico de Ecología, CSIC, Campus de Aula Dei, Avda Montañana 1005, Apartado 202, 50080-Zaragoza, Spain. Email: humberto@ipe.csic.es

Paper submitted on 23 October 2001 


\section{Introduction}

The last maximum glacial advance in many mountain ranges appears to have predated the last maximum advance of the Laurentide and Scandinavian continental ice-sheets (Marine Isotope Stage 2, around 20,000 yr B.P., Gillespie \& Molnar, 1995). The asynchronous advances and retreats of mountain and continental glaciers during the last glaciation have been explained in terms of different responses to similar global climate forcing, the effects of the local climate, and the peculiarities of mountain glaciers (Clapperton, 1993). However, the absence of an adequate chronological control of most mountain deglaciation sequences impedes comparison with global chronologies and tests for global synchroneity.

Glacial deposits in the Spanish Pyrenees have been studied since the 19th century (see references in Chueca et al., 1998). Most of them correspond to the last glaciation but some isolated moraine deposits are attributed to previous glacial cycles (Vilaplana, 1983; Serrano, 1992; Martí-Bono, 1996; Calvet, 1998). During the last 20 years, several geomorphological and glacial-geology studies in the Pyrenees have helped to identify and describe the main retreat, stillstand and advance phases after the Last Glacial Maximum (Vilaplana, 1983; Martínez de Pisón, 1989; Bordonau, 1992; Martí-Bono, 1996; Copons and Bordonau, 1996; Serrano, 1998). There are almost no absolute dates available for any of these episodes. Correlations between different valleys can only be made using topo-geomorphic methods and, consequently, it remains hypothetical. The timing of the maximum extent of the glaciers and the main deglaciation events are still one of the most significant problems of Pyrenean Quaternary geology. Several studies (Vilaplana, 1983; Montserrat, 1992; Bordonau, 1992) suggest that the maximum extent of Pyrenean glaciers occurred before 38,000 BP, long before the Last Glacial Maximum (LGM) as defined in marine (Ruddiman \& McIntyre, 1981; Maslin et al., 1995; Baas et al., 1997) and terrestrial records (Blunier et al., 1998; Petit et al., 1999; Mix et al., 2001). An early deglaciation has also been suggested for several valleys in the northern Pyrenean slopes (Montjuvent \& Nicoud, 1988; Andrieu et al., 1988) and other European mountain ranges, like the French Vosges (Seret et al., 1990), and the Alps (Chapron, 1999; Guiter et al., 2001), and recently in the Cantabrian Mountains (NW Spain, Ruiz-Zapata et al., 2000; JiménezSánchez \& Farias, in press). An early deglaciation could be a reflection of regional differences in the Alpine domain or related to geographical location (low latitude) and local factors (southern exposure, local climate). Detailed geomorphological studies of glacier retreat phases and absolute dating are needed to solve these controversies. The Upper Gállego River in the Central Spanish Pyrenees provides an excellent study area because it has well-preserved glacial deposits, extending from the outermost moraines 
to the most spatially restricted retreat phases (Martínez de Pisón \& Serrano, 1998), and several glacio-lacustrine deposits (Montserrat, 1992; Valero-Garcés \& Martí-Bono, 1997; Valero-Garcés \& Kelts, 1997). In this paper we present a detailed study of the glacial deposits of the Escarra and Lana Mayor valleys, two tributaries of the Upper Gállego River. Several ${ }^{14} \mathrm{C}$ AMS dates constrain the timing of the maximum glacier extent and the history of deglaciation in the Spanish central Pyrenees.

\section{Geographic and climatic setting}

The headwaters of the Gállego River are in the most humid sector of the Spanish Pyrenees. The average annual precipitation is around $2000 \mathrm{~mm}$ (García-Ruiz $\underline{e t}$ al., 1985), mainly concentrated between October and June, with a slight decrease in January and February. Most of the precipitation reflects movement of fronts from the Atlantic Ocean. The modern snow equilibrium line is at $2805 \mathrm{~m}$. The Pleistocene glaciers in the Gállego valley were the longest in the Spanish Western-Central Pyrenees (more than $30 \mathrm{~km}$ long), descending to $850 \mathrm{~m}$ a.s.l. During the Little Ice Age, the show equilibrium line was at $2618 \mathrm{~m}$ (López-Moreno, 2000), reaching $1900 \mathrm{~m}$ during the maximum glacier extent of the last glaciation (García-Ruiz et al., 2000).

The Escarra and Lana Mayor valleys are located in the northern slopes of the Sierra Telera (Fig. 1A) and are tributaries of the Upper Gállego Valley. Both valleys are underlain by Devonian and Carboniferous rocks (shales, quartzites, quartzitic sandstones and limestones), and bounded to the South by Cretaceous and Palaeocene limestones and sandstones (Fig. 1B). The headwaters of the Gállego River are underlain by Paleozoic granitic and sedimentary rocks and by Triassic sedimentary rocks. A large number of glacial deposits (moraine ridges, tills, proglacial lacustrine sediments) overlie the headwaters area of the Gállego River.

The Escarra Valley begins in El Rincón de Balsera, in a large cirque with steep backwalls of up to $2713 \mathrm{~m}$ in the Escarra Peak and $2697 \mathrm{~m}$ in the Águila Peak (Fig. 2). The cirque is carved in Cretaceous and Palaeocene rocks. Glacial erosion has excavated a typical U-shaped valley in the Paleozoic materials. The Lana Mayor Valley also has a large cirque that reaches $2763 \mathrm{~m}$ (Pala de Alcañiz Peak). This valley is wide and asymmetric with a strong contrast between the southern slope, formed by vertical cliffs carved in the Cretaceous and Paleocene rocks of Sierra Telera, and the central and northern areas, composed of Paleozoic quartzites and shales. Small cirques and avalanche channels fed the Lana Mayor Glacier from Sierra Telera. The divide between the Escarra and the Lana Mayor valleys was partially over-deepened by the glacier, resulting in a small basin occupied by a lake (Tramacastilla lake). After glacier retreat, several lakes formed behind the moraine deposits. Most were very small and filled with sediments very quickly. A few topographically-low areas are still occupied by lakes, such as the Piedrafita Lake, located behind a late moraine front. 


\section{Methods}

Mapping of glacial, lacustrine and moraine deposits was based on fieldwork and aerial photograph analysis. Pollen and sediment stratigraphy, ${ }^{14} \mathrm{C}$ dating and the organic matter content of the Tramacastilla Lake core can be found in Montserrat (1992). He dated the sediment record with eleven ${ }^{14} \mathrm{C}$ dates for the lake sequence plus two from the intercalated littoral peat layers. We re-sampled the core for mineralogy, organic and inorganic carbon and grain size analyses. Sediment mineralogy was determined by a Siemens D-500 diffractometer. The lacustrine sediment section located north of the Tramacastilla Lake was measured, described, and sampled.

Three cores, up to $2 \mathrm{~m}$ long, were retrieved from the Piedrafita Lake, using a modified Livingstone coring apparatus from a floating platform. The cores were described and correlated using lithological and sedimentological criteria. The sediment sequence was dated by ${ }^{14} \mathrm{C}$ AMS dates of bulk organic matter (peat) and a pine fragment samples (Valero-Garcés et al., 1998).

In the headwaters of the Gállego River, we cored a small peatbog close to the river (Corral de las Mulas peat bog, $<1 \mathrm{~m}$ long core) and a large peat bog (Portalet peat bog, $6 \mathrm{~m}$ long core) close to the mountain divide (Fig. 1A). The sediment sequence recovered from El Corral de las Mulas was less than one meter long and only a basal sample was taken for AMS dating. The $6 \mathrm{~m}$ long sediment core from El Portalet peatbog provides a sequence since deglaciation (González-Sampériz et al., 2001). Pollen was extracted from selected samples from the outcrop profiles and sediment cores by the classic chemical method (Dupré, 1992). Lycopodium spores were added to the samples to calculate pollen concentrations (Stockmarr, 1971).

The lack of an absolute chronology has hindered our understanding of the Pyrenean glaciation history. The absence of adequate organic material to date the moraines and the scarcity of lake deposits associated to the main glacial fluctuations impeded conventional radiocarbon dating. Glacial and fluvial deposits in the Upper Cinca valley (central Pyrenees, east of the Gállego river valley) have been dated using thermoluminescence techniques (Sancho et al., 2002) and the preliminary results indicate an early deglaciation (> $40 \mathrm{ka}$ ) in the Cinca valley. Pollen concentrates have provided enough material for AMS dating in organic-poor deposits in several sites from the Pyrenees and the Ebro Basin (Valero-Garcés et al., 2000). To test this possibility, several moraine deposits and lake deposits behind the moraine fronts in the Escarra and Lana Mayor valleys were sampled for pollen content. All of them were sterile. Several larger glacial lakes and peatbogs were cored and exposed lacustrine sections were sampled in order to obtain basal ages for the lake sequences. No organic macro-remains were found. However, the pollen content was enough to provide AMS dates. The pollen concentrates were obtained following the same chemical method used to prepare 
palynological samples. Two separate samples were prepared for each case in order to study the palynological composition, and to check for other organic remains that could contaminate the samples. The validity of the dates is discussed in the corresponding lake sections.

\section{Results}

\section{The Escarra Valley deglaciation sequence}

The Escarra Valley contains several moraine complexes, labeled in upper case letters in Fig. 2. The evolution of the ice masses for the Escarra and Lana Mayor glaciers is shown in Fig. 3. Because of the absence of absolute dates for the moraine deposits, the proposed glacial sequence summarized in Fig. 3 is the best-fit interpretation of the geomorphological evidence. Based on the geomorphological study of the glacial deposits, we proposed the following history as the most plausible for the retreat, advance and stillstand periods.

i) The maximum ice extent is marked by a moraine deposit at $1800 \mathrm{~m}$ a.s.l., near the Tramacastilla Lake (Fig. 2, A and Fig. 3-1 and 3-2). This upper level would correspond to a moraine ridge $(1840 \mathrm{~m})$ on the northern margin of the valley (Fig. 2, A1) and to other small till accumulations (Fig. 2, A2). During this period, the ice was $230 \mathrm{~m}$ thick over the modern Escarra Reservoir, which allowed for several transfluences towards the Lana Mayor Valley (through the Tramacastilla divide) and towards the Gállego main glacier (Fig. 2, A3). The deposits belonging to the maximum ice extent mainly comprise Paleozoic rock fragments with an abundant greyish-bluish matrix. Devonian quartzites and sandstones (between 45 and 60\%) and black limestones (around 50\%) are dominant. Cretaceous and Palaeocene limestones and sandstones content is always less than $10 \%$.

Two periods of glacier stillstand were identified after the maximum: two moraine ridges at 1760 and $1740 \mathrm{~m}$, close to the Tramacastilla lake (Fig. 2, B) and two more on the right margin of the Escarra Reservoir, around 1730 m (Fig. 2, B1). Although close proximity does not guarantee similar age, the similar lithology of all these deposits suggests that they are related to the glacial maximum extent. The thinning of the ice did not preclude ice flow over the Tramacastilla divide towards the Lana Mayor Valley. However, the transfluences to the Gállego main glacier were already ice-free.

1. A unique deposit also related to the maximum ice extent is located in the Ordecito Ravine (Fig. 2, A4). Almost all the boulders are Cretaceous sandstones (45\%) and Cretaceous and Palaeocene limestones (45\%), whereas the Paleozoic sandstones and quartzites represent less than $10 \%$, and the Devonian black limestone clasts are 
less than 2\%. This deposit was clearly laid down by ice from the Lana Mayor Valley, coming through a transfluence pass.

ii) After the glacial maximum extent, the ice retreated a long distance towards the upper part of the valley. Later, a re-advance of the Escarra glacier occurred but it was much more spatially restricted than the previous stage. During this advance two lateral moraines were deposited (Fig. 2, C to C6 and Fig. 3-3). The terminal area was probably located around the middle zone of the Escarra Reservoir. An ice lobe went towards the Tramacastilla Lake but it did not pass over the divide.

The tills deposited during this stage are composed of Paleozoic sandstones and limestones (70\%), shales (11\%), Cretaceous sandstones (11\%), Cretaceous and Palaeocene limestones (4\%) and greywackes (4\%). The matrix, still very abundant, has the same greyish-bluish color than the older tills.

iii) The third moraine complex is topographically higher, and it was deposited when the Escarra glacier developed a 4 km long ice-tongue (Fig. 2, D and Fig. 3-4). It is composed of three frontal arcs, elongated by well-developed lateral ridges. The most important feature of this moraine complex is the dominance of Cretaceous and Palaeocene sandstones and limestones. The fine matrix also has a conspicuous brown color, very distinctive from the older tills. The three frontal arcs are composed of big, non-striated blocks. These deposits are interpreted to be a re-advance from the cirque, where the glacier incorporated the Cretaceous and Palaeocene blocks.

iv) A big frontal arc is easily identified in the Rincón de Balsera (Fig. 2, E and Fig. 3-5). It extended upwards, especially on its left margin. This moraine complex is a chaotic mixture of poorly-sorted, non-striated blocks with long $a$ axes (several meters in some cases). This deposit shows an irregular topography, with many depressions and ridges, and without clear lineations. We interpret this deposit as the remains of a debriscovered glacier that advanced during a period of especially intense rock-fall from the cirque backwalls. During this time, the ice tongue was slightly longer than $2 \mathrm{~km}$, with a maximum thickness of 80-100 m.

v) A large moraine ridge is located very close to the backwall of the Rincón de Balsera cirque (Fig. 2, F). It had large, angular, sharp, non-striated Cretaceous and Palaeocene sandstone and limestone pebbles with a scarce fine matrix. The arc corresponds to the last glacial stage (represented by a small ice plaque), partially functioning as a protalus rampart. More recently, the lower part of the cirque backwall was occupied by a scree talus.

\section{The Lana Mayor deglaciation sequence}

Fig. 2 shows the moraine deposits (lower case letters) from the Lana Mayor Valley and Fig 3 shows the proposed glacial evolution based on the geomorphological evidence. 
i) The maximum extent of the Lana Mayor glacier can be assessed from two transfluence deposits and a large moraine deposit east of the Piedrafita Lake (Fig. 2,a1 and Fig 3-1 and 3-2). The first transfluence corresponds to the pass of the Lana Mayor ice toward the Escarra Valley, which left a patchy till cover in the headwater area of the Ordecito Creek (Fig. 2, A4). The ice was around 200-250 m thick. The second transfluence corresponds to the pass of the Escarra ice toward the Lana Mayor Valley through the Tramacastilla Lake divide. Here, the Escarra glacier left several small moraine deposits (Fig. 2, a1) that contain Devonian quartzites and limestones, confirming that the Escarra valley was the source area. The ice thickness would have been around $175 \mathrm{~m}$ thick and the glacier was probably connected with the Gállego glacier.

There are two large north-south moraine ridges east of the Piedrafita Lake (Fig. 3, a1) culminating at 1677 and $1697 \mathrm{~m}$. They are exclusively composed of Cretaceous and Palaeocene clasts from the Sierra Telera cliffs.

ii) Several ridges located immediately south of the Tramacastilla lake divide represent a secondary maximum stage (Fig. 2, b and Fig. 3-3). The ridges are well defined and incorporate small depressions with glaciolacustrine sediments. We were not able to date these sediments due to the very low pollen concentration. The lithology of the ridges is dominated by Cretaceous and Palaeocene sandstones (70\%) and limestones (28 \%). This composition demonstrates that ice moved from the Lana Mayor Valley, and that there was no transfluence from the Escarra Valley through the Tramacastilla divide at that time. During this period, the Lana Mayor glacier was confined inside the valley, forming one or two thin ice masses towards the northnortheast.

iii) Several north-south ridges identified above the previous moraines (Fig. 2, c), suggest that the Lana Mayor glacier was divided into two independent ice masses during this period.

iv) There is evidence of two debris-covered glaciers, similar to those described in the Escarra Valley (Fig. 2, d and Fig. 3-5).

v) The most recent advance corresponds to a series of lobate moraine ridges at the foot of the Sierra Telera cliff (Fig. 2, e and Fig. 3-6). All were apparently related to small ice plaques fed by avalanche channels. Once the ice disappeared, a scree accumulation developed and it remains active today.

The glacial lake records

The Tramacastilla and Piedrafita lakes

The Tramacastilla Lake is located in a low divide, formerly occupied by a glacial tongue that moved from the Escarra glacier to the Lana Mayor glacier. There are many patchy till deposits close to the lake (Figs. 2 and 3). Several moraines in the 
Escarra valley near the lake are around $100 \mathrm{~m}$ above the divide. Consequently, the maximum ice thickness over the divide is estimated to have been around $100 \mathrm{~m}$. The glacier excavated a small basin in the divide that was occupied by a lake after its retreat. The Tramacastilla catchment is very small and composed of Devonian sandstones and shales, with only small ephemeral creeks feeding the lake. The Tramacastilla Lake core was described from a palynological and sedimentological point of view by Montserrat (1992). Detailed sedimentological and mineralogical studies performed on the same cores provided more information on the paleohydrological and paleolimnological changes in the lake (Valero-Garcés \& MartíBono, 1997 and Valero-Garcés \& Kelts, 1997). Fig. 4 shows the main vegetational events, the sediment stratigraphy, the total carbon content, the grain-size distribution and the mineralogy of the core.

The lower $4.3 \mathrm{~m}$ of the sequence comprises massive fine silts ("Blue Clays" facies) with low organic matter, relatively low quartz and feldspar content and relatively high carbonate content. The fine grain size, the greyish-bluish color and the high carbonate content in the "blue clays" indicates that the sediment source was glacier moraine deposits from valleys with carbonate rocks. The silts were deposited during glacial times when the lake was directly fed by glacier melt water. Pollen stratigraphy (Montserrat, 1992; Jalut et al., 1992) indicated an Artemisia Chenopodiaceae- Poaceae steppe indicating a cold and arid continental climate. Montserrat (1992) provided a conventional ${ }^{14} \mathrm{C}$ date on bulk organic matter at $11.8 \mathrm{~m}$ depth of $29,400 \pm 600{ }^{14} \mathrm{C}$ years $\mathrm{BP}$ that suggested that the ice had already retreated to the headwaters of the valleys by $30 \mathrm{ka}$. The presence of significant amounts of carbonate in the basal sediments raises the possibility of hard-water effects and contamination by "old carbon". In order to test the hypothesis of an early glacial maximum, other glacial lakes in the area were cored and the results are presented in the next sections.

There was an abrupt change in the sediment mineralogy at the onset of the deposition of the Lower Clastic Unit, around 20,000 BP (Fig. 4). The coarser silt-sand rhythmites and laminated black silts of the Lower Clastic Unit are devoid of carbonates and their quartz and feldspar content was much higher. A detailed mapping of the glacial features suggested that a change in the surface hydrology was responsible for this lithological change. Originally, the creek that drained to the lake (Tramacastilla Ravine) had a larger basin (130 ha), covered by a thick moraine deposit composed of Cretaceous and Palaeocene limestone and calcareous sandstone. These moraines were deposited by the Lana Mayor glacier through a transfluence pass. The Ordecito Ravine (Fig. 5) captured the headwater of the Tramacastilla Ravine after a large landslide, reducing the catchment of the Tramacastilla Lake to 16 ha, and blocking any source of carbonate material to the lake. As a result of these changes, the watershed reduced to 
the surrounding Devonian shales and sandstones, and the sediments deposited in the lake became coarser. The age of the landslide should coincide with the disappearance of carbonate sediments in the Tramacastilla lake record (around 20,000 ${ }^{14} \mathrm{C}$ years B.P.). The occurrence of a landslide in this area also indicates that the glacier had already retreated further up the valley at that time.

Cores from the Piedrafita Lake only provide information about the last 4000 years (Valero-Garcés et al., 1998). Sandy layers prevent further penetration and the substrate was not reached. The $1.5 \mathrm{~m}$ long sequence contains carbonate-rich mud, clastic silt and sand, and thin peat layers. The intercalated peat layer in the upper part of the sequence could be a reflection of lower lake levels during the Little Ice Age.

\section{The Northern Tramacastilla Lake Sequence}

Lacustrine sediments crop out on the northern slope of the Escarra - Lana Mayor divide. They were deposited in a glacial lake that was drained and partially eroded. The former basin of the lake was dammed to the north by several small, rounded hills. These small hills are not moraine deposits but outcrops of Paleozoic shales. They are part of the landslide that changed the course of the Ordecito Creek (Fig. 5). The changes in the surface hydrology induced by this landslide around 20,000 yr B.P. were apparently responsible for both the origin of this small lake basin and the changes in sedimentary conditions in the Tramacastilla Lake.

The stratigraphic section of this deposit is shown in Fig. 6. The lower part of the 4 $\mathrm{m}$ thick section is composed of decimeter-thick sets of poorly-sorted, coarse gravel, overlain by upward fining sequences of gravel-sand-silt. The middle part is composed of fine silt. The upper part includes gravel and $1 \mathrm{~m}$ of upward fining silts. These sediments were deposited in a lacustrine environment influenced by fluvial-deltaic conditions. Two sediment samples were taken at 350 and $275 \mathrm{~cm}$ depth for pollen analyses and ${ }^{14} \mathrm{C}$ AMS dating of the pollen concentrates. The first one was sterile and the latter one had very low pollen concentrations (around 3,000 grains/ gram). The pollen spectrum indicates a cold steppe dominated by non-arboreal taxa (75\%) with Poaceae, Helianthemum, and other taxa typical of open formations, such as Chenopodiaceae, Carduaceae, Artemisia and Centaurea. There are less than $5 \%$ of some meso-thermophylous taxa (Abies, Corylus, Alnus, Fraxinus, Quercus type faginea-pubescens and type- ilex). The presence of similar small amounts of such thermophilous pollen grains is common in many Pyrenean sites, and it has been considered either as an evidence for long-distance transport (Mardones, 1982) or for contamination from older sediments (Reille, 1990; Andrieu, 1991). Long distance transport (more than $1500 \mathrm{~km}$ ) of pollen taxa such as Pinus, but also other mesophilous taxa such as Tilia, Quercus and Alnus has been described in modern tundra environments in Canada (Lichti-Federovich \& Ritchie 1968; Ritchie et al., 1987). The 
similar conservation stage of all the pollen grains and the absence of any indication of secondary reworking are considered evidence for long distance rain (Diot, 1991). The ${ }^{14} \mathrm{C}$ AMS date from the pollen concentrate at this level was 20,600 \pm 170 years BP (AZ-35870). A hard-water effect is unlikely, because of the absence of any pollen from aquatic plants, and the non-carbonate nature of the sediments, On the other hand, the scarce presence of thermophilous pollen grains and the absence of evidence for reworking, suggest that all the pollen grains were synchronous to deposition and favor the validity of this age.

\section{The Gállego River valley lake deposits}

Montserrat (1992) reported a lacustrine sequence in a doline about $20 \mathrm{~km}$ upvalley of the maximum extent of the Gállego glacier. Although hard-water effects are possible in this environment, the basal date at this site suggested that the area was already deglaciated by $20,800{ }^{14} \mathrm{C}$ yr B.P. By that time, the glacier had almost disappeared even from some of its source areas. This is the case of the Formigal area, where the age of basal sediments deposited in a lake dammed by a large landslide (Corral de las Mulas peatbog) is $20150 \pm 150$ yr B.P. (AZ-35867). The sediments are also carbonate-poor. Pollen concentration is about 32,000 grains/gr. The pollen spectrum indicates a cold steppe similar to the Northern Tramacastilla sequence and dominated by non-arboreal taxa (70\%) as Poaceae and Helianthemum, and with the presence of other taxa typical of open formations, as Chenopodiaceae, Carduaceae, Artemisia and Centaurea. The arboreal pollen assemblage is dominated by Pinus (20 $\%$ ) and Juniperus (5\%). The remaining $5 \%$ of arboreal pollen is mostly composed of

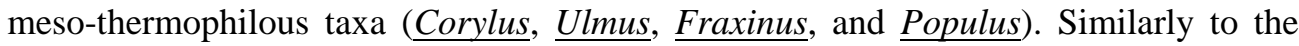
basal sample from the Northern Tramacastilla sequence, these pollen grains have likely been transported from known glacial refuges in the Pre-Pyrenees and the Ebro valley (Sanchez-Goñi \& Hannon, 1999; Valero-Garcés et al., 2000).

Finally, the Portalet peatbog located in the upper part of the Gállego River basin (1980 m a.s.l.) within a small glacial cirque, provides another minimum age for the deglaciation (Fig. 7). The basal age of the lacustrine section from a $6.40 \mathrm{~m}$ long core that reached the glacial till gave an age of $>28,300 \pm 370$ yr B.P. (NSRL-11969). Sediments are also carbonate-poor. Pollen data from the basal samples showed typical glacial assemblages characterized by low pollen concentrations (1950 grains/gram), high percentages of Artemisia (up to $30 \%$ ) and low arboreal pollen contents (20\%) dominated by Pinus and Juniperus. The Artemisia - Chenopodiaceae- Poaceae Helianthemum - Ephedra t. dystachia steppe suggests a cold and arid continental climate. No mesophilous taxa or aquatic plants are present in these samples, and consequently, the ages are considered valid. 


\section{Discussion: a > 30,000 yr BP maximum glacier advance and a smaller LGM re-advance in the Central Spanish Pyrenees.}

The occurrence of a large number of moraines and glaciolacustrine deposits in the Escarra and Lana Mayor valleys provides an excellent case-study for glacial geology and also the opportunity to establish a relative sequence of glacial advance and retreat stages, from the maximum glacial extent to the final phases during the Little Ice Age.

During the maximum glacial extent, ice covered most of the area in both valleys with many transfluences between them, and it also extended to the Gállego Valley. Ice depth exceeded $200 \mathrm{~m}$ in the middle Escarra Valley. The maximum extent moraine complex included two lower stillstand or minor re-advance episodes (Fig. 3.1).

This pattern is similar to other Pyrenean valleys deglaciation sequences. There are three lateral moraine ridges in the Gállego (García-Ruiz \& Martí-Bono, 1994; Martí-Bono, 1996; Serrano, 1998), Ésera (Martínez de Pisón, 1989; García-Ruiz et al., 1992), Hecho (Martí-Bono, 1996) and Ara (García-Ruiz \& Martí-Bono, 1994) valleys associated with the maximum glacial extent. The terminal basin of the Aragón Valley (Martí-Bono, 1996) also has several frontal arcs. Several episodes related to the maximum extent of the glaciers can also be found in other Spanish mountains (Martínez de Pisón \& Alonso, 1992).

The timing of the maximum ice extent in the Pyrenees is still under debate. Dates from the glaciolacustrine sequence of Biscaye (French Pyrenees, Mardonès \& Jalut, 1983) indicate than the maximum must be before 38,000 BP. Bordonau (1992) suggests 45,000-50,000 BP and Vilaplana \& Montserrat (1989) suggest between 70,000 and 50,000 BP. In the case of the Escarra and Lana Mayor valleys the best evidence comes from the basal date of the Tramacastilla sequence $\left(29,400 \pm 600{ }^{14} \mathrm{C}\right.$ B.P., Montserrat,1992). Obviously, the maximum extent of the glaciers had to be somewhat earlier since the moraines related to the maximum were around $100 \mathrm{~m}$ over the Tramacastilla Lake divide. The possibility of hard-water effects cannot be ruled out and the validity of this date remains under discussion. However, new ages from other deposits presented here, also support an early deglaciation. According with the basal age of the Portalet peatbog sequence, the headwaters of the Gállego River were already deglaciated and small proglacial lakes have developed at altitudes up to $2000 \mathrm{~m}$ prior to $20 \mathrm{Ka}$. Preliminary thermoluminescence dates from glacial and fluvial deposits in the Upper Cinca valley (east of the Gállego river valley) also support an early deglaciation (> $40 \mathrm{ka}$ ) in this valley (Sancho et al., 2002).

This early age for the maximum extent of Pyrenean glaciers does not coincide with the evolution of the Scandinavian Ice Sheet. Although a maximum extent of the Scandinavian/British ice sheets at ca. 20 ka B.P. has been challenged by Sejrup et al 
(1994), most studies indicate that both the maximum cold and extent occurred around 20,000 BP (Mangerud, 1991; Andersen \& Borns, 1994). The maximum advance of the Jura glaciers and some of the large Alpine Swiss and Italian glaciers (Magny, 1995) also occurred during the Upper Würm (Marine Isotope Stage 2). However, the maximum extent of many other Alpine glaciers was during the Middle Würm (MIS 3) before 38,000 yr B.P. (Chapron, 1999). These data correlate well with results from other moraine sequences in the Massif Central (Etlicher \& De Goer de Herve, 1988), Vosges (Seret et al., 1990), and Pyrenees (Andrieu et al., 1988). Several valleys have evidence of early glacial retreat in the northern slopes of the Pyrenees including Gave de Pau, Gave d' Ossau and the Garonne valley (Andrieu et al., 1988). All these dates indicate that the farthest advance of glaciers in the Pyrenees preceded 38,000 - 27,000 ${ }^{14} \mathrm{C}$ yr B.P.

A secondary glacial advance in the Escarra and Lana mayor valleys is delimited by some lateral moraines at the margins of relatively small glacial tongues (Fig 3.3). A similar secondary stage has been found in most Pyrenean glacial sequences (Vilaplana, 1983; Bordonau, 1992; Martí-Bono, 1996) and it has been called the "Valley Glaciers Phase" (Bordonau, 1992). During this time, the Escarra and Lana Mayor ice tongues were not connected with the Gállego glacier. Although few absolute dates are available in the Pyrenean region, the advance is considered to have occurred around 20,000 to 25,000 yr BP, coinciding with the coldest period of the last glaciation (MIS 2). By that time, the glaciers were also at higher elevation in the French Pyrenees (Andrieu et al., 1988). According to our new dates from the Escarra valley, the second glacial advance terminated before $20,000{ }^{14} \mathrm{C}$ yr B.P. The occurrence of laminated lacustrine clays at the base of the northern Tramacastilla Lake sequence indicates that the glacier front was already located farther up-valley at about $20,600{ }^{14} \mathrm{C}$ yr B.P.

Three later minor stages of glacier advance have been identified in the Escarra and Lana Mayor valleys and they can be correlated with similar three stages in other Pyrenean glacial sequences. The geomorphological study suggests that the glaciers of these last three stages advanced from the cirque backwalls and that the short periods between stages represented an almost complete melting of the ice masses. Although the absence of absolute dates for the moraine deposits in most Pyrenean valleys makes the proposed correlation somehow speculative, it is the best-fit interpretation of the geomorphological evidence and the limited available absolute ages. During the first phase of this new glacial advance, the glacier in the Escarra Valley was longer than 4 km, and the Lana Mayor glacier was subdivided into two small ice masses (Fig. 3.4). This stage can be geomorphologically correlated with the "Upper Valley Glaciers Phase" defined by Bordonau (1992) and dated between 16,000 and 15,000 BP (end of the last pleniglacial). A cooling episode at this time is clearly recorded in the Antarctic and Greenland ice cores (Blunier et al., 1998; Petit et al., 1999) and in the ocean 


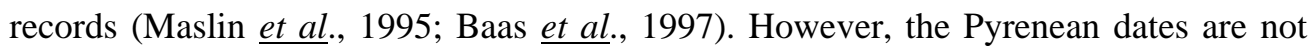
calibrated, and therefore it is difficult to establish an accurate comparison with the calibrated ages from the ice cores.

The debris-covered glaciers represent a subsequent, short advance with a large debris input from the cirque backwalls (Fig. 3.5). This stage ("Debris-covered Glaciers Phase" or "Cirque Glaciers Phase") occurred between 14,000 and 13,000 BP in other Pyrenean valleys (Bordonau 1992; Copons \& Bordonau, 1996; Copons \& Bordonau 1997).

The last stage represented by large moraines close to the cirque backwalls (Fig. 3.6) could be ascribed to the "Rock Glacier Phase" (Serrat, 1979; Bordonau, 1992. The relationship of this phase with the Younger Dryas cooling episode remains speculative due to the lack of absolute dates.

Several hypotheses have been put forward to explain the asynchronous maximum advances in Pyrenean mountains and continental glaciers. The coldest phases of the last glacial period, the Dansgaard-Oeschger stadials, were very dry in central and southern Iberia (Sánchez-Goñi et al., 2000, 2002). No detailed Dansgaard-Oeschger paleoclimate records from northern Iberia are available, but because of the strong Mediterranean influence in the southern Central Pyrenees, it is likely these stadials were also dry, which could limit the expansion of the Pyrenean glaciers. During these periods the North Atlantic Ocean was frozen at relatively low latitudes, reducing the humidity content of the air masses and fronts that affected the Iberian Peninsula (Mix et al, 2001). Consequently, it is possible that a cold period that caused an expansion of the glaciers in Northern Europe, produced a more modest expansion in the low latitude glaciers, such as those in the Pyrenees.

There are few records in the Iberian Peninsula that span beyond the LGM, and, consequently, moisture and temperature reconstructions, and the pattern of regional variability are not conclusive (see references in Sánchez-Goñi et al., 2000, 2002, Valero-Garcés et al., 2000). Most of the Iberian records document several humid and arid periods since the LGM. Some sequences point to a period of increased effective moisture in the Iberian Peninsula immediately after the Last Glacial Maximum. Deepwater sedimentary facies and a large negative $\delta^{18} \mathrm{O}$ excursion in the Banyoles Lake core suggest a large hydrological change in the lake, immediately after the LGM - dated as $22,890 \pm 310{ }^{14} \mathrm{C}$ yr BP and $18,000 \mathrm{U} / \mathrm{Th}$ yr BP - that could be related to a period of increased effective moisture in north-eastern Spain (Valero-Garcés et al., 1998). 
Similarly, the SST reconstructions based on cores offshore Portugal suggest relatively mild surface temperature (only about $5^{\circ} \mathrm{C}$ lower than modern SST) during the LGM in the strictest sense (21,000 $\pm 2000 \mathrm{cal} \mathrm{yr} \mathrm{B.P.)} \mathrm{(Bard} \mathrm{et} \mathrm{al.,} \mathrm{2000).} \mathrm{Oxygen} \mathrm{isotopes} \mathrm{and}$ dinoflagellate cyst records from a nearby core (Boessenkool et al., 2001) also show a distinct warm episode around the last glacial maximum. These data are consistent with other interpretations from regional marine cores (Bard et al., 1987). However, pollen records from marine show evidence for increased precipitation - but not for temperature changes - during the LGM (Turon et al., 2002). Pollen records from marine cores offshore Portugal show an alternation of deciduous and evergreen Quercus woodland with open vegetation which reflects a succession of temperate and cold environments in Iberia during the period 50,000 - 30,000 yr B.P. (Sánchez-Goñi et al., 2000). They correspond with Heinrich events and with most of the Dansgaard-Oeschger oscillations. Polar water advances during the last interglacial complex, correlate with increased steppe-like vegetation in Iberia (Sánchez-Goñi et al., 1999; 2000, 2002). Most pollen records in Spain suggests increased aridity during the Lateglacial cold events (Pons \& Reille, 1988; Pérez-Obiol and Julià, 1994; Peñalba et al.,1997; Jalut et al., 1992). However, there are some significant differences among Heinrich events during the last glacial cycle in southwestern Europe, and on land, the last glacial period seems to have been progressively cooler towards the LGM. Cold and arid conditions in Iberia during the H3 event seem to be related more to a combined response of the melting of the European ice sheet and a decrease in insolation than to large iceberg surges from the Laurentide ice-sheet (Sánchez-Goñi et al., 2000).

Changes in global atmospheric circulation patterns may also have had an impact on mountain glacier fluctuations. Clapperton (1993) suggests that some glaciers in South America were less extensive around 20,000 yr B.P. because of reduced precipitation. The shifting of the storm tracks, the reduced available moisture due to colder seas in higher latitudes and the lowered sea level would have had a synergic effect in reducing the precipitation over the continents. In North America, global circulation models indicate that the Laurentide ice sheet split the circumpolar jet stream at the peak of the last glaciation (around 20,000 yr B.P.) and changed the amount of moisture available to the southern arm of the storm track affecting the mountain glaciers of the southern Rocky Mountains. In Europe, the LGM jet stream was shifted equatorward and passed over the Pyrenees and south of the Alps, although it was farther north earlier in the glacial cycle (MIS 3 and 4) (Ruddiman \& McIntyre, 1981; 
Maslin et al., 1995). However, the dynamics of the jet stream is much more complex than previously thought (Mix et al.,2001). The extreme cooling and dryness during the Heinrich events 5 and 4 in the Mediterranean region has been explained by the development and persistence of both Scandinavian and Atlantic Mobile Polar Highs over southwestern Europe (Sánchez-Goñi et al., 2002). Precipitation gradients between the more humid Atlantic and the drier Mediterranean sides of the Iberian Peninsula have occurred during the glacial cycle, but they intensified during Heinrich events 4 and 5. It is therefore possible that there were large fluctuations in moisture in the Pyrenees and the Alps and it is reasonable to expect that the local glacial maximum (and maximum ice extent) could have occurred at different times in different mountain ranges. Andrieu et al. (1988) report that increased aridity in Western Europe during the LGM is the main reason for a smaller advance of mountain glaciers. However, in the Swiss and Austrian Alps the maximum advance seems to occur later and closer to the global LGM. The emerging picture of an E-W gradient, with the biggest glaciers occurring earlier in the West and later in the East, needs to be tested with detailed chronologies.

\section{Conclusions}

The study of the former extent of glaciation in Escarra and Lana Mayor catchments and the upper parts of the Gállego River Basin provides further evidence for a maximum ice extent in the Pyrenees earlier than for the Scandinavian ice-sheets (> 30,000 yr B.P.). Similar conclusions have been drawn for several valleys in the northern Pyrenean slopes (Montjuvent \& Nicoud, 1988; Andrieu et al., 1988), the French Vosges (Seret et al., 1990), the eastern Pyrenees (Sancho et al., 2002), the Alps (Chapron, 1999; Guiter et al., 2001), and the Cantabrian Mountains (NW Spain, RuizZapata et al., 2000; Jiménez-Sánchez \& Farias, in press). The global Last Glacial Maximum corresponding with the maximum global ice volume (around 20,000 BP) was synchronous with an increase in precipitation over the center and southern Iberia, along with the increase in the sea surface temperature of the Iberian margin (references). This global LGM coincided (or is preceded in the Pyrenees) with a glacial re-advance, which did not reach the extent of the earlier maximum ice extent in the mountain glaciers. Comparison with other Pyrenean valleys demonstrates that five glacial stages can be identified for the whole Pyrenean domain. More sedimentological and palynological studies and absolute dates are needed in order to establish a chronological framework for the main deglaciation events. They will provide a test for the non-synchronous timing of the Scandinavian ice-sheet expansions and those of the Pyrenean glaciers. 


\section{Acknowledgements}

This work was part of the Project "Isotope sedimentology of 40 ka time-series from Iberian sites as a test for abrupt arid/humid switching within the Mediterranean climate zone" (EAR 941-8657), funded by the National Science Foundation, USA, and the Project "Arid periods in the Mediterranean area since the Last Glacial Maximum" (REN2000-1136/CLI), funded by the Spanish "Comisión Interministerial de Ciencia y Tecnología”. The authors thank Dr. Colin Ballantyne, Dr. Valérie Andrieu-Ponel and Dr. María Fernanda Sánchez-Goñi for their criticisms and suggestions that improved the manuscript.

\section{References}

ANDERSEN, B.G. and BORNS Jr., H.W. 1994. The ice age world. Scandinavian University Press, 208 pp., Oslo.

ANDRIEU, V. 1991. Dynamique du paléoenvironnement de la vallée montagnarde de la Garonne (Pyrénées centrales, France) de la fin des temps glaciaires à l'actuel. Thèse Nouveau Régime, Université de Toulouse 2, 330 p.

ANDRIEU, V., EICHER, U., and REILLE, M. 1993. La fin du dernier pléniglaciare dans las Pyrénées (France): données polliniques, isotopiques et radiométriques. Comptes Rendus de l' Ácadémie des Sciences de Paris, t. 316, Série II, 245-250.

ANDRIEU, V., HUBSCHMAN, J., JALUT, G. and HERAIL, G. 1988. Chronologie de la deglaciation des Pyrénées françaises, Dynamique de sedimentation et contenu pollinique des paléolacs: application à l' interpretation du retrait glaciare. Bull. Assoc. Fr. Etude Quat., 2/3, 55-67.

BAAS, J.H., MIENERT, J., ABRANTES, F. and PRINS M.A., 1997. Late Quaternary sedimentation on the Portuguese continental margin: climate-related processes and products. Palaeogeography, Palaeoclimatology, Palaeoecology, 130: 1-23

BARD , E., ARNOLD, M., MAURICE, P., DUPRAT, J. MOYES, J. and DUPLESSY, J.C. 1987. Retreat velocity of the North Atlantic polar front during the last deglaciation determined by 14C accelerator mass spectrometry. Nature 328: 791794.

BARD, E., ROSTEK, F., TURON, J.-L., GENDREAU, S. 2000. Hydrological impact of Heinrich events in the subtropical Northeast Atlantic. Science 289: 1321-1324.

BLUNIER, T. 1998. Asynchrony of Antartic and Greenland climate change during the last glacial period. Nature, 394: 739-743.

BOESSENKOOL,K.P., RINKHUIS, H., SCHÖNFELD, J. and TARGARONA, J. 2001. North Atlantic sea-surface temperature changes and the climate of western 
Iberian during the last deglaciation; a marine palynological approach. . Global and Planetary Change, 30: 33-39.

BORDONAU, J. 1992. Els complexos glacio-lacustres relacionats amb el darrer cicle glacial als Pirineus. Geoforma Ediciones, 251 pp., Logroño.

CALVET, M. 1998. Los complejos fluvioglaciares de Cerdanya-Capcir (Pirineos orientales) y sus enseñanzas. IN: Gómez Ortiz, A. and Pérez Alberti, A. (eds.), Las huellas glaciares de las montañas españolas, Universidad de Santiago de Compostela, pp. 263-290, Santiago de Compostela.

CHAPRON, E. 1999. Controles climatique et sismo-tectonique de la sédimentation lacustre dans l'avant-pays alpin (Lac du Bourget) le Quaternaire récent. Géologie Alpine, Memoire H.S. 30, 261 p. Université Joseph Fournier, Grenoble.

CHUECA, J., PEÑA, J.L., LAMPRE, F., GARCÍA-RUIZ, J.M. and MARTÍ-BONO, C. 1998. Los glaciares del Pirineo aragonés: estudio de su evolución y extensión actual. Departamento de Geografía, Universidad de Zaragoza, 104 pp., Zaragoza.

CLAPPERTON, C. M. 1993. Quaternary Geology and geomorphology of South America, 779 pp. Elsevier, New York.

COPONS, R. and BORDONAU, J. 1996. El registro sedimentario del Cuaternario reciente en el lago Redó d'Aigües Tortes (Pirineos centrales). Cadernos do Laboratorio Xeolóxico de Laxe, 21, 249-260.

COPONS, R. and BORDONAU, J. 1997. El último ciclo glacial (Pleistoceno SuperiorHoloceno) en el macizo de la Maladeta (Pirineos centrales). Rev. Soc. Geol. Española, 10 (1-2), 55-66.

DIOT, M.F. 1991. Le palynofacies en archéologia: intérêt de son etude. Révue Aquitania, 4: 91-97.

DUPRÉ, M. 1992. Palinología. Cuadernos Técnicos de la SEG, 5, 1-30.

ETLICHER, B. and DE GOER DE HERVE, A. 1988. La déglaciation würmienne dans le Massif Central français: le point des travaux récents. Bull. Assoc. Fr. Etude Quat., 2/3, 103-110.

GARCÍA-RUIZ, J.M., PUIGDEFÁBREGAS, J. and CREUS, J. 1985. Los recursos hídricos superficiales del Alto Aragón. Instituto de Estudios Altoaragoneses, 224 pp., Huesca.

GARCÍA-RUIZ, J.M. and MARTÍ BONO, C. 1994. Rasgos fundamentales del glaciarismo cuaternario en el Pirineo aragonés. IN: Martí-Bono, C. and GarcíaRuiz, J.M. (eds), El glaciarismo surpirenaico: Nuevas aportaciones, Geoforma Ediciones, pp. 17-32, Logroño.

GARCÍA-RUIZ, J.M., BORDONAU, J., MARTÍNEZ DE PISÓN, E. and VILAPLANA, J.M. 1992. Mapa geomorfológico. Benasque. Geoforma Ediciones, 39 pp., Logroño. 
GARCÍA-RUIZ, J.M., ORTIGOSA, L., GÓMEZ-VILLAR, A. and MARTÍ-BONO, C. 2000: Morphometry of glacial cirques in the Spanish Pyrenees. Geografiska Annaler, 82A, 433-442.

GILLESPIE, A. and MOLNAR, P. 1995. Asynchronous maximum advances of mountain and continental glaciers. Reviews of Geophysics , 33 (3), 311-364.

GONZÁLEZ-SAMPÉRIZ, P., VALERO-GARCÉS, B.L., MARTÍ, C., GARCÍARUIZ, J.M., LORENTE, A.,and BEGUERIA, S. 2001. Holocene environmental change in the Upper Gállego valley (western Spanish Pyrenees):climate, environment and human impact. Terra Nostra, 12: 37-41.

GUITER, G., ANDRIEU-PONEL, V., BEAULIEU, J.L. (de), VANNIÈRE, B., BOSSUET, G., TRIGANON, A., BLAVOUX, B., NICOUD, G. 2001. The Würmian glaciation in the Geneva basin: reconstruction of the vegetation dynamics in a context of successive ice retreat. Past Climate variability through Europe and Africa PAGES-PEP III Meeting Abstract Book, Aix-en-Provence, 9091.

JALUT, G., MONTSERRAT, J., FONTUNGE, M., DELIBRIAS, G., VILAPLANA, J. and JULIÁ, R. 1992. Glacial to interglacial vegetation changes in thenorthern and southern Pyrenees: deglaciation, vegetation cover and chronology. Quaternary Science reviews 11: 449-480.

JIMÉNEZ SÁNCHEZ, M. \& FARIAS, P. (in press). New radiometric and geomorphologic evidences of Last Glacial Maximum older than 18 ka in SW European Mountains: the example of Redes Natural Park (Cantabrian Mountains, NW Spain). Geodinamica Acta

LITCHI-FEDEROVICH, S. and RITCHIE J.C. 1968. Recent pollen assemblages from Western Interior of Canada. Rev. Palebot. Palyn., 7: 297-344.

LÓPEZ-MORENO, J.I. 2000: Los glaciares del alto valle del Gállego (Pirineo Central) desde la Pequeña Edad del Hielo. Implicaciones en la evolución de la temperatura. Geoforma Ediciones, 77 pp., Logroño.

MAGNY, M. 1995: Une histoire du climat. Errance Ed., 176 pp., Paris.

MANGERUD, J. 1991. The last interglacial/glacial cycle in northern Europe. IN: Shane, L.C.K. and Cushing, E.J. (eds.), Quaternary landscapes, University of Minnesota Press, pp. 38-75, Minneapolis.

MARDONÈS, M. 1982. Le Pléistocène supérieur et l'Holocène du piémont de Lourdes: le gisement de Biscaye (Hautes Pyrénées, France). Etude palynologique, sédimentologique et géomorphologique. Thèse Université de Toulouse 2, 100 p.

MARDONÈS, M. and JALUT, G. 1983. La tourbière de Biscaye (alt. 409 m, Hautes Pyrénées): approche paléoécologique des 45.000 dernières années. Pollen et Spores, 25 (2), 163-212. 
MARTÍ-BONO, C. 1996. El glaciarismo cuaternario en el Alto Aragón Occidental. Tesis Doctoral, Facultat de Geología, Universitat de Barcelona, 254 pp., Barcelona.

MARTÍNEZ DE PISÓN, E. 1989. Morfología glaciar del valle de Benasque (Pirineo aragonés). Ería, 18, 51-64.

MARTÍNEZ DE PISÓN, E. and ALONSO, F. 1992. Algunas reflexiones sobre el glaciarismo en las montañas españolas. Cuadernos de Sección. Historia, 20, 109121.

MARTÍNEZ DE PISÓN, E. and SERRANO, E. 1998. Morfología glaciar del valle de Tena (Pirineo aragonés). IN: Gómez Ortiz, A. and Pérez Alberti, A. (eds.), Las huellas glaciares de las montañas españolas, Universidade de Santiago de Compostela, pp. 239-261, Santiago de Compostela.

MASLIN, M.A., SHACKLETON, N.J., and PFLAUMANN, U. 1995. Surface water temperature, salinity, and density changes $n$ the northeast Atlantic during the last 45,000 years. Paleoceanography 10 (3): 527-544.

MIX, A.C., BARD, E. and SCHNEIDER. 2001. Environmental processes of the ice age: land, oceans , glaciers (EPILOG). Quaternary Science Reviews 20: 627-657.

MONTJUVENT, G. and NICOUD, G. 1988: Modalités et chronologie de la déglaciation würmienne dans l'arc alpin occidental et les massifs français: synthèse et réflections. Bull. Assoc. Fr. Etude Quat., 2/3, 147-156.

MONTSERRAT, J. 1992. Evolución glaciar y postglaciar del clima y la vegetación en la vertiente sur del Pirineo: Estudio palinológico. Instituto Pirenaico de Ecología, 147 pp., Zaragoza.

PEÑALBA, M.C., ARNOLD, M., GUIOT, J., DUPLESSY, J.C. and DE BEAULIEU, J.L 1997. Termination of the Last Glaciation in the Iberian Peninsula inferred from the pollen sequence of Quintanar de la Sierra. Quaternary Research, 48 : 205-214.

PÉREZ OBIOL, R. and JULIÀ, R. 1994. Climatic Change on the Iberian Peninsula recorded in a 30,000-yr pollen record from Lake Banyoles. Quaternary Research, 41: 91-98.

PETIT, J.R., PETIT, J., JOUZEL, D., RAYNAUD, N. I., BARKOV, J.-M., BARNOLA, I., BASILE, M., BENDER, J., CHAPPELLAZ, M., DAVIS, G., DELAYGUE, M., DELMOTTE, V. M., KOTLYAKOV, M., LEGRAND, V. Y., LIPENKOV, C., LORIUS, L., PÉPIN, C., RITZ, E., SALTZMAN,, M. and STIEVENARD 1999. Climate and atmospheric history of the past 420,000 years from the Vostok ice core, Antarctica. Nature, 399: 429-436. 
PONS, A. and REILLE, M., 1988. The Holocene and Upper Pleistocene pollen record from Padul (Granada, Spain): a new study. Palaeogeography, Palaeoclimatology, Paleoecology, 66: 243-263.

REILLE, M. 1990. La tourbière de La Borde (Pyrénées orientales, France): un site clé pour l'étude du Tardiglaciaire sud-européen. Comptes Rendus de l'Académie des Sciences de Paris, tome 310, série 2, 823-829.

RITCHIE, J.C., HADDEN, K.A. and GAJEWSKI, K. 1987. Modern pollen spectra from lakes in Artic western Canada. Canadian Journal of Botany, 65: 1605-1613.

RÍOS, L.M., GALERA, J.M., BARETTINO, D. and LANAJA, J.M. 1989. Mapa geológico de España escala 1: 50.000. Hoja de Sallent de Gállego no 145. IGME, Madrid.

RUDDIMAN, W.F. and MCINTYRE, A. 1981. The North Atlantic Ocean during the last deglaciation. Palaeogeography, Palaeoclimatology, Paleoecology,35: 145214.

RUIZ ZAPATA, B., JIMÉNEZ SÁNCHEZ, M., GIL GARCÍA, M.J., DORADO VALIÑO, M., VALDEOLMILLOS RODRÍGUEZ, A., and FARIAS P. 2000. Registro palinológico de un depósito postglaciar en el Parque Natural de Redes (Cordillera Cantábrica, Noroeste de España): Implicaciones paleoclimáticas. Geotemas, 1 (4): 279-283.

SANCHO, C., PEÑA, J.L., LEWIS, C., MCDONALD, E., and RHODES, E. 2002. Preliminary dating of glacial and fluvial deposits in the Cinca River valley (NE Spain). IN: Ruíz-Zapata B. (Ed) Quaternary climatic changes and environmental crises in the Mediterranean region, Alcalá de Henarés (in press).

SÁNCHEZ-GOÑI, M.F. and HANNON, G. 1999. High-altitude vegetational pattern on the Iberian Mountain chain (north-central Spain) during the Holocene. The Holocene, 9: 39-57.

SÁNCHEZ-GOÑI, M.F., EYNAUD, F., TURON, J.L., and SHACKLETON,N.J. 1999. High resolution palynological record off the Iberian margin: direct land-sea correlation for the Last Interglacial complex. Earth and Planetary Science Letters, 171: 123-137.

SÁNCHEZ-GOÑI. M.F., TURON, J.-L-, EYNAUD, F. and GENDREAU, S. 2000. European climatic response to millennial scale changes in the atmosphere-ocean system during the last glacial period. Quaternary Research, 54: $394-$ 403 .

SÁNCHEZ-GOÑI, M.F., CACHO, I., TURON, J.-L-, GUIOT, J., SIERRO, F.J., PEYPOUQUET, J.P., GRIMALT, J.O., and SHACKLETON, N.J. 2002. 
Synchroneity between marine and terrestrial responses to millennial scale climatic variability during the last glacial period in the Mediterranean region. Climate Dynamics, 19: 95-105.

SEJRUP , H.P., HAFLIDASON, H., AARSETH, I., KING, E., FORSBERG, C.F., LOND, D. and ROKOENGEN, K. 1994. Late Weichselian glaciation history of the northern North Sea. Boreas, 23: 1-13.

SERET, G., DRICOT, E. and WANSARD, G. 1990. Evidence for an early glacial maximum in the French Vosges during the last glacial cycle. Nature, 346, 453456.

SERRANO, E. 1992. Huellas de una glaciación pre-pleniglaciar en la Ribera de Biescas (cuenca del Gállego, Pirineo aragonés). Cuadernos de Sección. Historia, 20, 213227.

SERRANO, E. 1998. Geomorfología del Alto Gállego, Pirineo aragonés. Institución Fernando El Católico, 501 pp., Zaragoza.

SERRAT, D. 1979. Rock glacier moraine deposits in the eastern Pyrenees. IN: Schlüchter, C. (ed), Moraines and varves, Balkema, pp. 93-100, Rotterdam.

STOCKMARR, J. 1971. Tablets with spores used in absolute pollen analysis. Pollen et Spores, 13, 614-621.

TURON J.L. 2002. Land-sea correlations for the last glaciation inferred from a pollen and dinocyst record from the Portuguese margin. Quaternary Research (in press).

VALERO-GARCÉS, B. and KELTS, K. 1997. Desertificación y cambio global en la península Ibérica durante el último ciclo glacial a partir de registros lacustres. IN: Ibáñez, J.J., Valero-Garcés, B. and Machado, C. (eds.), El paisaje mediterráneo a través del espacio y del tiempo. Implicaciones en la desertificación, Geoforma Ediciones, pp. 419-438, Logroño.

VALERO-GARCÉS, B. and MARTÍ-BONO, C. 1997. Degradación ambiental e impacto antrópico: técnicas y aportaciones desde la limnogeología. IN: GarcíaRuiz, J.M. and López-García, P. (eds.), Acción humana y desertificación en ambientes mediterráneos, Instituto Pirenaico de Ecología, pp. 99-118, Zaragoza.

VALERO GARCÉS, B., MARTÍ-BONO, C. and KELTS, K. 1998. El Holoceno superior en el valle de Tena, Pirineos occidentales españoles. IN: Gómez Ortiz, A. and Salvador, F. (eds.), Investigaciones recientes de la Geomorfología española. Sociedad Española de Geomorfología, pp. 463-469, Barcelona.

VALERO GARCÉS, B., GONZÁLEZ-SAMPÉRIZ, P., DELGADO-HUERTAS, A., NAVAS, A., MACHÍN, J. and KELTS, K. 2000. Late Glacial and Late Holocene environmental and vegetational change in Salada Mediana, Central Ebro Basin, Spain. Quaternary International, 73/74: 29- 46. 
VALERO-GARCÉS, B.L., ZEROUAL, E. and KELTS, K. 1998. Arid phases in the western Mediterranean region during the Last Glacial Cycle reconstructed from lacustrine records. - In: Benito, G., Baker, V.R., and Gregory, K.J. (eds.), Paleohydrology and Environmental Change. Wiley and Sons, London, p. 67-80.

VILAPLANA, J.M. 1983. Estudi del glaciarisme quaternari de les altes valls de la Ribagorça. Tesi Doctoral, Dept. de Geomorfologia i Tectònica, Universitat de Barcelona, 322 pp., Barcelona.

VILAPLANA, J.M. and MONTSERRAT, J. 1989. Recent progress in Quaternary stratigraphy: The lake Llauset sequence in the Spanish Pyrenees. IN: Rose, J. and Schlüchter, C. (eds.), Quaternary type sections: Imagination or reality?, Balkema, pp. 113-124, Rotterdam. 


\section{FIGURE CAPTIONS}

Fig. 1. A. Location map of the Escarra and Lana Mayor valleys within the Upper Gállego Valley. Legend: 1. Main mountain divides.

B. Geological map of the study area (After Ríos et al., 1989. 1: Shales (Devonian); 2: Limestones (Devonian and Carboniferous); 3: Sandstones and shales (Carboniferous Culm facies); 4: Limestones and sandy limestones (Cretaceous); 5: Sandstones and marly sandstones (Cretaceous); 6: Limestones and dolomites (Paleocene); 7: Sandstones and marls (Flysch facies of the Eocene); 8: Thrust; 9: Fault; 10: Tectonic contact; 11: Normal contact.).

Fig. 2. Geomorphological map of the Escarra and Lana Mayor valleys. 1: Glacial cirques. 2: Main moraine ridges. 3: Secondary moraine ridges. 4: Ice flow in the transfluence passes. 5: Moraine accumulations. 6: Scars of large landslides. 7: Landslide tongues. 8: Large rock avalanches. 9: Former glacial lakes, infilled with sediment. 10: Avalanche couloirs channels. 11: Structural cliffs. 12: Divides. 13: Main peaks. 14: Lakes and reservoirs, 15. Villages.

Fig. 3: Extent of the Escarra and Lana Mayor glaciers during the different phases identified in this paper. 1: Main maximum Ice Extent. 2: Secondary maximum ice extent. 3: Valley Glaciers Phase (secondary maximum at the end of the Upper Pleistocene). 4: Upper Valley Glacier Phase. 5: Debris-covered Glaciers Phase (Cirque Glacier Phase). 6: Final Phase (Wall Glaciers Phase or Rock Glaciers Phase).

Fig. 4. Summary of the sedimentological and palynological record of the Tramacastilla Lake (Montserrat, 1992; Valero-Garcés et al., 1998)

Fig. 5. The capture of the Ordecito Ravine at about $20000{ }^{14} \mathrm{C}$ yr B.P. A. Pre-landslide situation; the Tramacastilla Creek fed directly the Tramacastilla Lake. B. Post-landslide situation; the upper reach of the Tramacastilla creek is captured by the Ordecito ravine and the lower reach is isolated from the headwaters. Other landslides north of Tramacastilla lake block the outlet from this lake and create another lake (The northern Tramacastilla paleolake). 1. Fluvial network; 2. Moraines with limestone clasts; 3. Landslide accumulation; 4. Ordecito landslide scar.

Fig. 6. The sedimentological record of the Northern Tramacastilla Lake Sequence.

Fig. 7. The sedimentological record of the Portalet Peatbog core and the palynological record for the basal lacustrine deposits.

TABLE 1. Radiocarbon dates from basal lake deposits associated to moraines. 
Table 1. Radiocarbon dates from bottom lake deposits associated to moraines.

\begin{tabular}{|l|l|l|l|l|l|l|}
\hline Sample & Lab number & Material & $\begin{array}{l}\text { S13C } \\
\text { (per mill PDB })\end{array}$ & $\begin{array}{l}\text { Fraction of } \\
\text { modern 14C }\end{array}$ & $\begin{array}{l}\text { 14C age yrs } \\
\text { BP }\end{array}$ & Age Error \\
\hline $\begin{array}{l}\text { Tramacastilla } \\
\text { paleolake }\end{array}$ & AZ- 35870 & $\begin{array}{l}\text { Pollen } \\
\text { concentrate }\end{array}$ & -26.1 & 0.0770 & 20,600 & 170 \\
\hline $\begin{array}{l}\text { Tramacastilla } \\
\text { Lake }\end{array}$ & GIF-8239 & $\begin{array}{l}\text { Bulk organic } \\
\text { matter }\end{array}$ & - & - & 29,400 & 600 \\
\hline Formigal & AZ-35867 & $\begin{array}{l}\text { Pollen } \\
\text { concentrate }\end{array}$ & -24.6 & 0.0817 & 20,120 & 150 \\
\hline $\begin{array}{l}\text { Portalet } \\
\text { peatbog }\end{array}$ & NSRL-11969 & $\begin{array}{l}\text { Pollen } \\
\text { concentrate }\end{array}$ & -22.7 & 0.02936 & 28,300 & 370 \\
\hline $\begin{array}{l}\text { Piedrafita } \\
\text { Lake }\end{array}$ & WHOI 17539 & wood & - & 0.6304 & 3710 & 60 \\
\hline
\end{tabular}



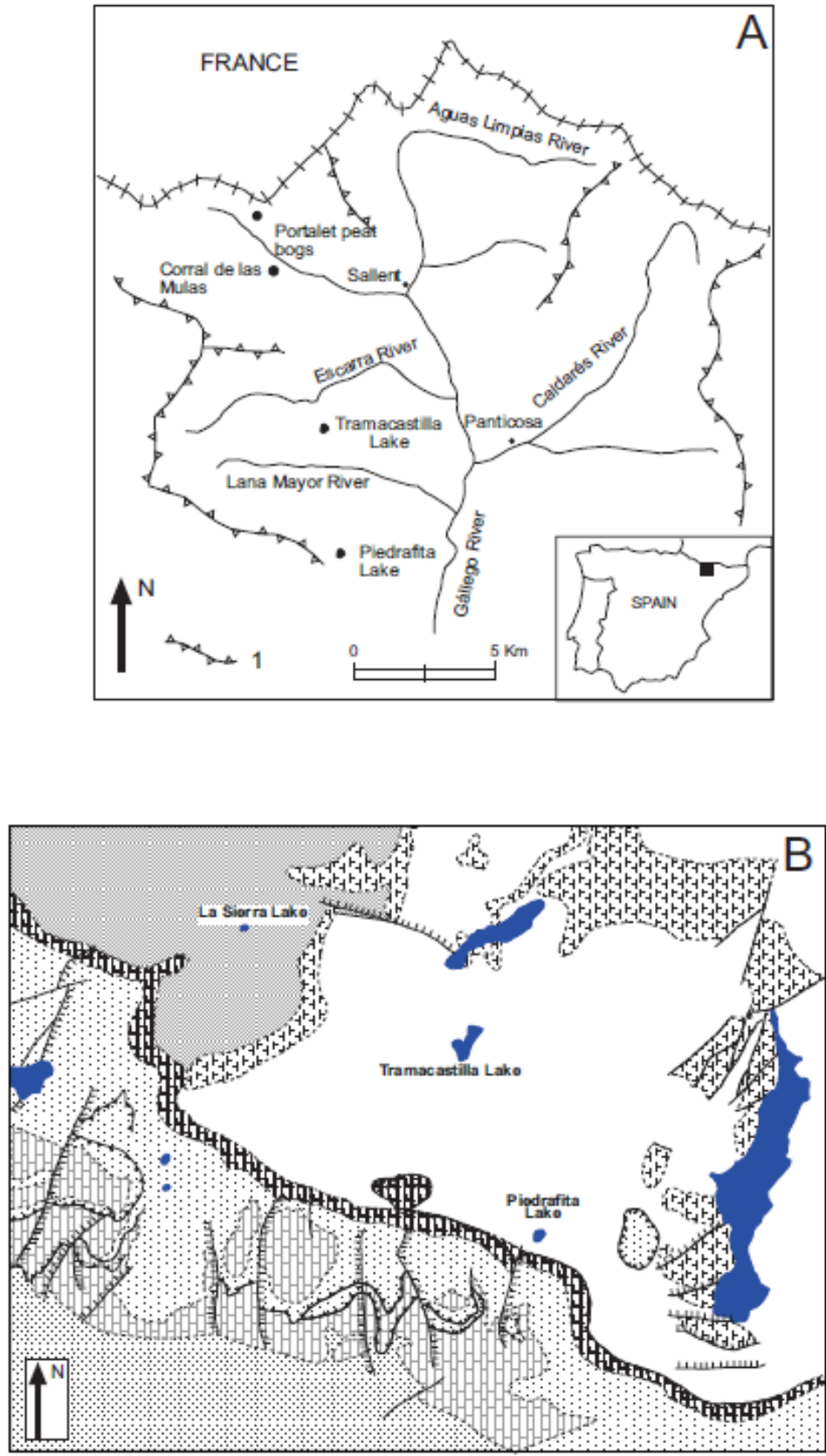

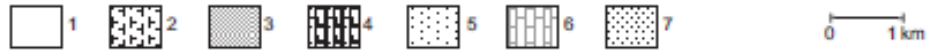
${ }^{8}{ }^{8} \mathrm{nnm}^{9}-{ }^{10}$-.--- 11

Fig 1 


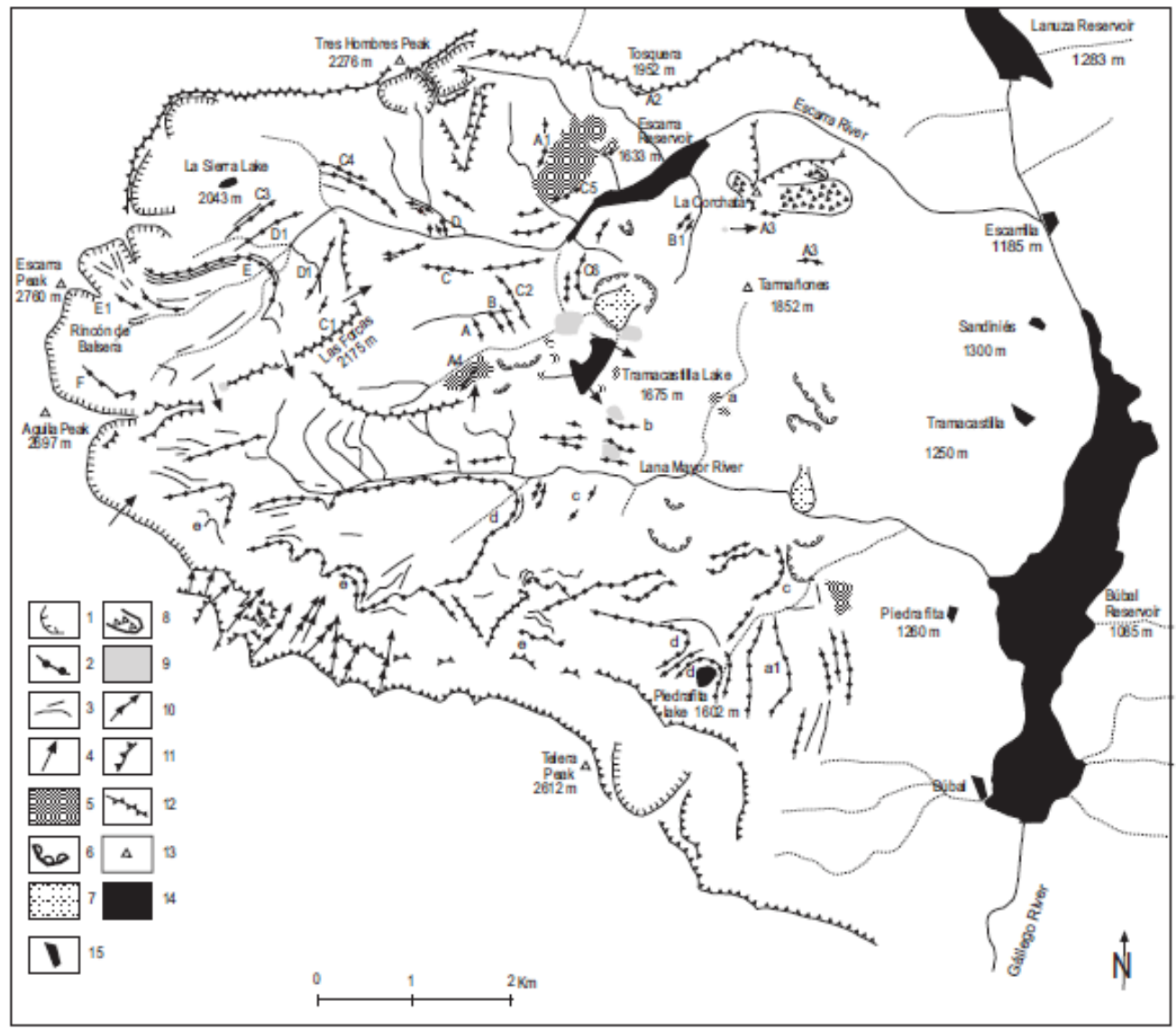

Fig 2 

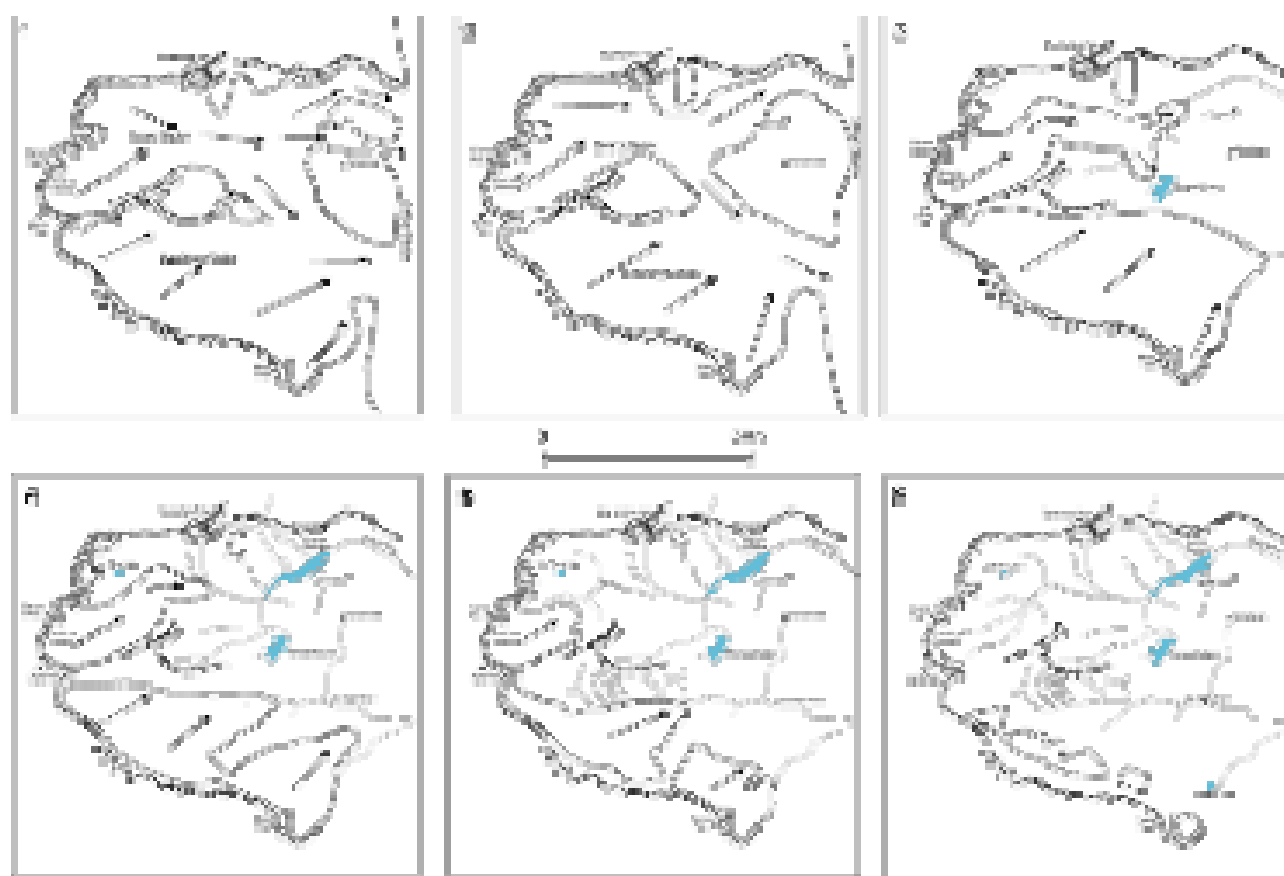

ian
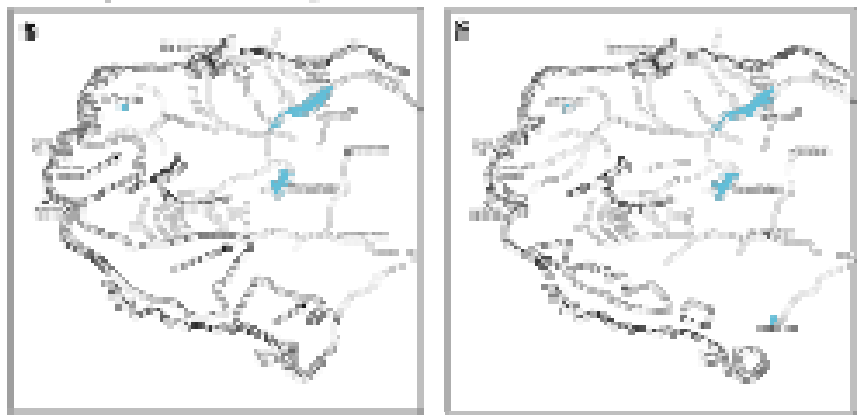

Fig.3 


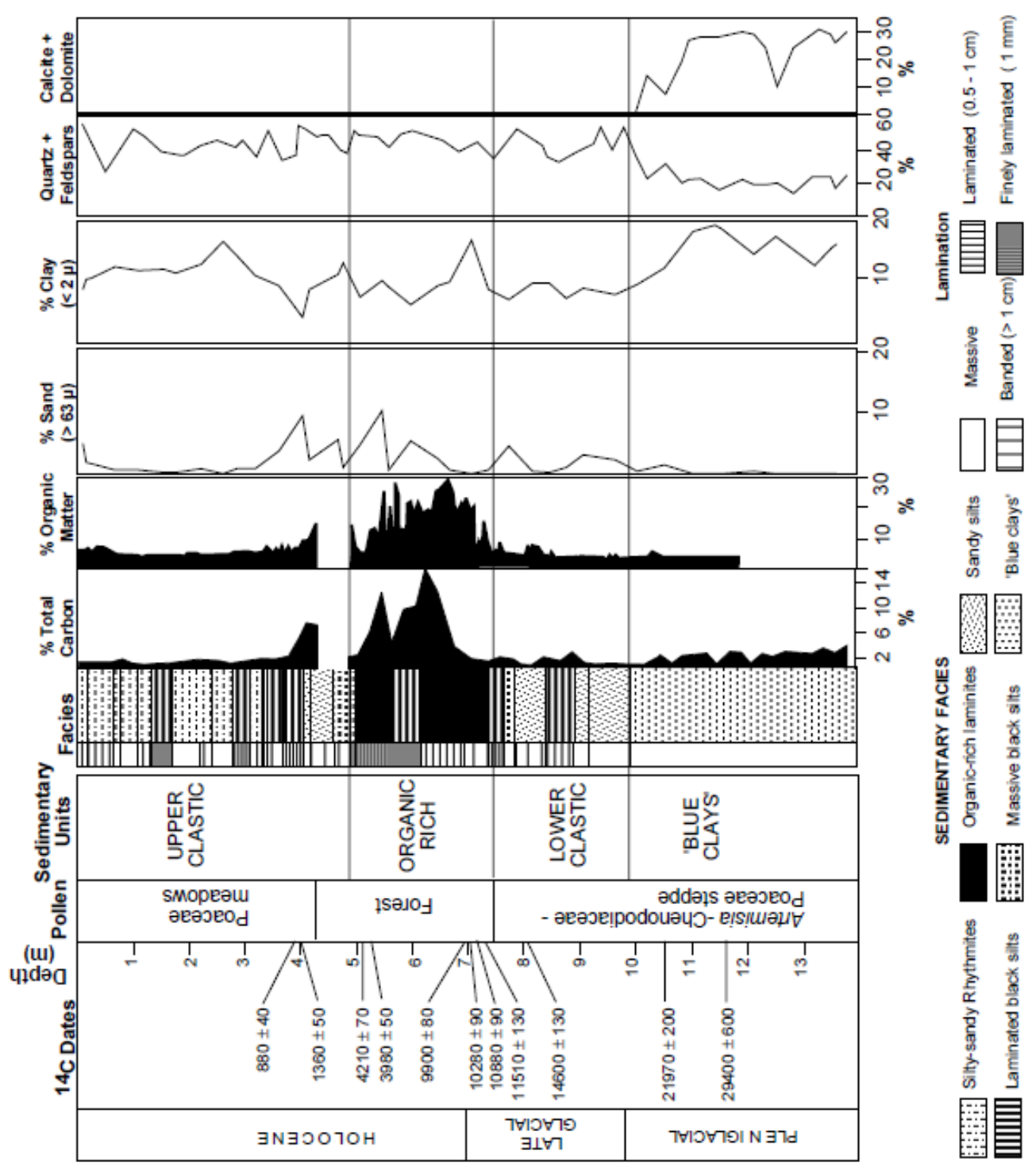

Fig 4 

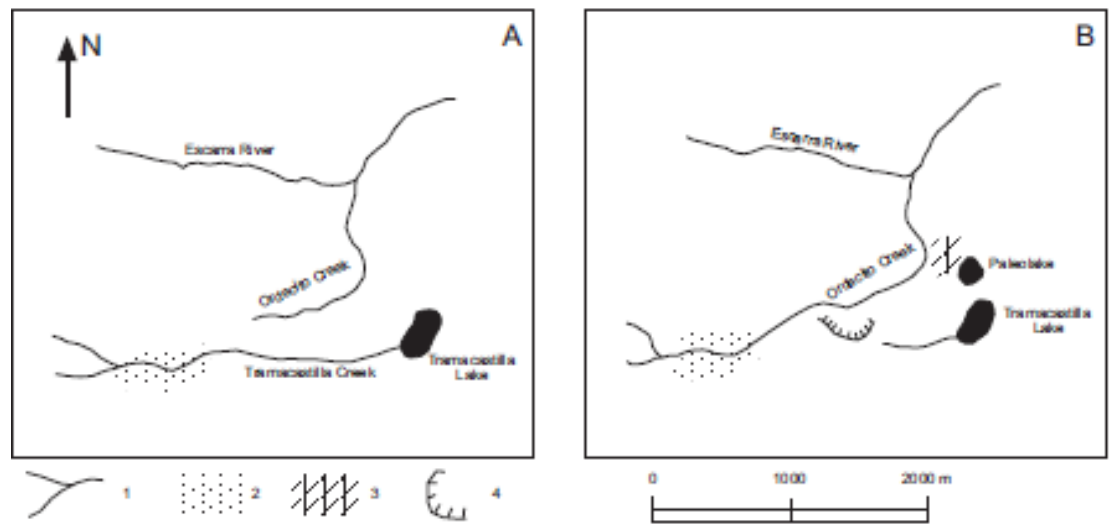

Fig 5 


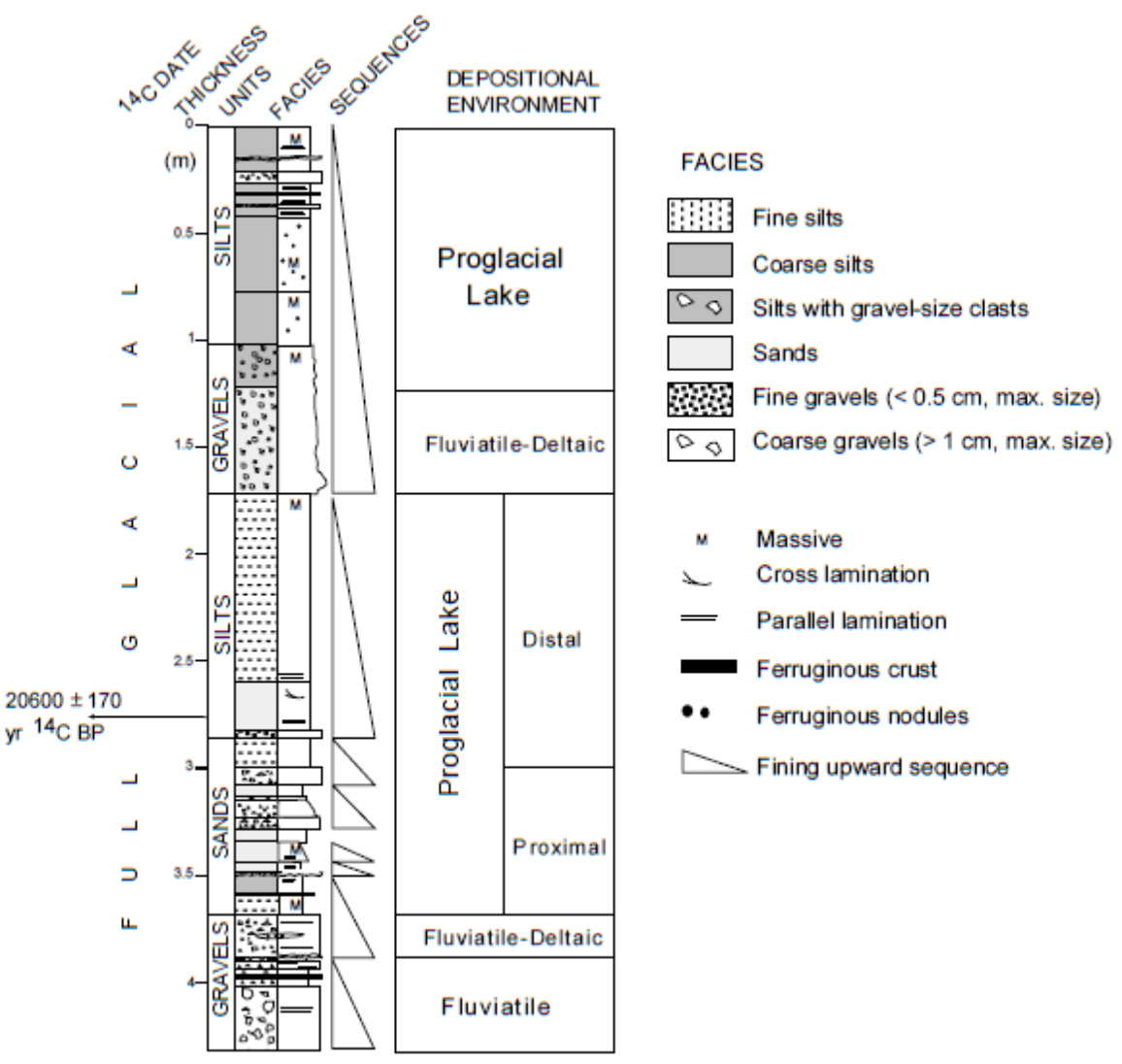

Fig 6 


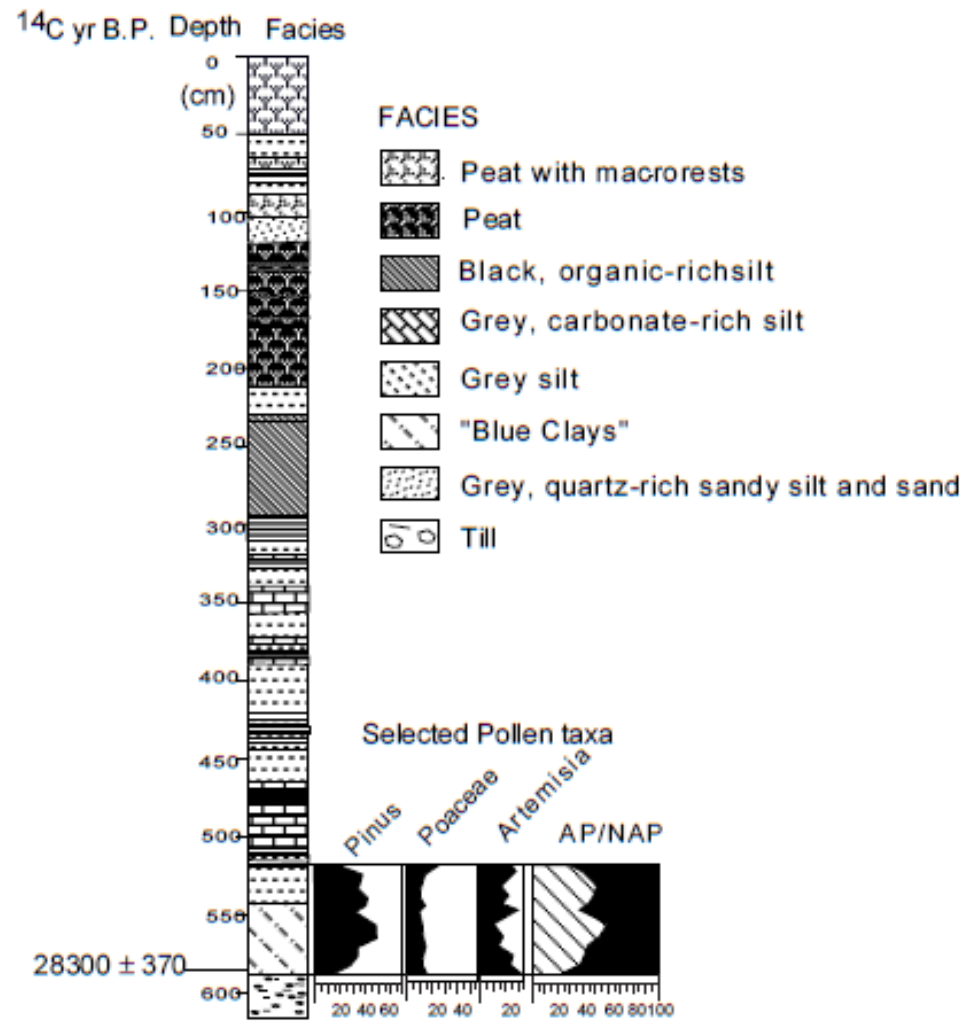

Fig 7 